DOI 10.22460/infinity.v7i1.p45-54

\title{
THE DIFFERENCE OF STUDENTS' MATHEMATICAL ACHIEVEMENT BY USING GUIDED-DISCOVERY AND COOPERATIVE LEARNING MODEL JIGSAW TYPE
}

\author{
Anna Angela Sitinjak ${ }^{1}$, Herman Mawengkang ${ }^{2}$ \\ ${ }^{1,2}$ University of Sumatera Utara, Medan, Jl. Bioteknologi No.1, Medan, North Sumatera, Indonesia \\ ${ }^{1}$ annaangelasitinjak@gmail.com, ${ }^{2}$ hmawengkang@yahoo.com
}

Received: October 25, 2017 ; Accepted: January 24, 2018

\begin{abstract}
The type of this study is a quasi-experiment study with its purpose to know any difference in students' achievement in mathematics which using the model of guided discovery learning with cooperative learning model JIGSAW type. The population of this study is all students in SMA N 3 P. Siantar. The sampling technique applied was cluster random sampling. The experimental class I that chosen is X-1 consisted of 36 students, meanwhile, the experimental class II that chosen is X-6 consisted of 36 students. The instrument used to measure the students' mathematics achievement was an essay test. The normality test used was Lilliefor's test, get that data is normal and the homogeneity test by using Fisher test, get that data is homogeny. The data analysis technique was t-test at the level of significance $\alpha=5 \%$. The study result showed that there is the difference of students' achievement in mathematics which using the guided discovery learning model with cooperative learning model JIGSAW type in grade X SMA N 3 P. Siantar where obtained $t_{\text {calculation }}=2.504$ at $\alpha=0.05$ and $\mathrm{t}_{\text {table }}=\mathrm{t}_{(0.975,70)}=1.995$, then $\mathrm{t}_{\text {calculation }}>\mathrm{t}_{\text {table }}$.
\end{abstract}

Keywords: Guided Discovery, JIGSAW, Mathematics Achievement.

\begin{abstract}
Abstrak
Penelitian ini termasuk pada penelitian eksperimen tipe kuasi dengan bertujuan untuk mengetahui perbedaan prestasi siswa terhadap matematika yang menggunakan model pembelajaran penemuan terbimbing dengan model pembelajaran koperatif tipe JIGSAW. Populasi penelitian adalah siswasiswa SMA N 3 P.Siantar. Dengan menggunakan "cluster random sampling", dipilih sampel untuk kelas eksperimen I adalah X-1 dengan 36 siswa dan kelas eksperimen II adalah X-6 dengan 36 siswa. Instrumen yang digunakan untuk mengukur prestasi siswa berbentuk esai. Data yang diteliti adalah normal dan homogen setelah diuji dengan Liliefors dan Fisher. Teknik analisis data menggunakan ttest dengan $\alpha=5 \%$. Hasil penelitian ini menunjukkan bahwa ada perbedaan prestasi siswa terhadap matematika yang menggunakan model pembelajaran penemuan terbimbing dengan model pembelajaran koperatif tipe JIGSAW dimana diperoleh $t_{\text {hitung }}=2.504$ at $\alpha=0.05$ and $t_{\text {tabel }}=$ $\mathrm{t}_{(0.975,70)}=1.995$, maka $\mathrm{t}_{\text {hitung }}>\mathrm{t}_{\text {tabel }}$.
\end{abstract}

Kata Kunci: Hasil Belajar Matematis, JIGSAW, Penemuan Terbimbing.

How to Cite: Sitinjak, A. A., \& Mawengkang, H. (2018). The Difference of Students' Mathematical Achievement by using Guided-Discovery and Cooperative Learning Model Jigsaw Type. Infinity, 7 (1), 45-54. doi:10.22460/infinity.v7i1.p45-54. 


\section{INTRODUCTION}

Mathematics is the science which is very important to be mastered, because it is indispensable in daily life. In order to achieve the goals of learning mathematics, it is needed the role of various components such as: students, teachers, learning indicators, subject content, learning model, methods, media, and evaluation. Teacher as one component of teaching and learning activity has a very important role in achieving the learning objectives and determine the success of the educational process. Teacher must be able to motivate their students to engage in the teaching and learning process.

Unfortunately, it is not easy to motivate students, especially senior high school students to be active in teaching and learning activities because teachers often apply the traditional learning model. So most of the teachers directly provide mathematical formulas to the students and the students only see and memorize the formulas. So do not be surprised if they think math is very bored and dreaded. They think if they cannot memorize formulas they will get low score at math test and worse when they just memorize formulas without knowing the actual math concepts (how to get the formula). As the result, when teachers give a different question from the example, the students are confusedand fell difficult to solve it. So the math scores of students are still low.

Martunis, Ikhsan \& Rizal (2014) says that to study mathematics is required a good understanding of the concept in which in order to form the new concept understanding, necessary understanding of the concept before. However, as revealed by Hendriana, Hidayat, \& Ristiana (2018) that many children after studying mathematics, simple part was much he did not understand, because many of the concepts are misunderstood, which means that the students' understanding of the concept of the low. The learning and teaching process which is implemented by teacher at the class is classically and only rely on textbooks with a teaching method that emphasizes the process of memorizing rather than understanding the concept. So that when students are given problems or test, will have difficulty in solving and can get low score. The low of students' achievement for mathematics in Indonesia is also proved from the results of international research (Hidayat, 2017).

This problem is also occurred in SMAN 3 Pematangsiantar. The math teacher of SMA N 3 Pematangsiantar complained that the score average of daily math test is still around 60 whereas KKM (minimum passing criteria) in that school is 75 . It indicates that it does not achieve the value of KKM for math. Based on data obtained from DKN in grade X SMA N 3 Pematangsiantar, the average of students' achievement for mathematics also has not been satisfactory that is just 61.7 .

One of the ways is refinement to the arranging and application of learning models used by the teacher. The learning model which is appropriate, effective and making the students closed to the teacher will make students enjoy to study and be more active, so students can improve their understanding of mathematics. From some existing learning models, one way to deal with the above problem is by guided-discovery learning model. Discovery learning can be defined as the learning that takes place when the student is not presented with the subject matter in the final form, but rather is required to organize it himself (Janssen, Westbroek, \& van Driel, 2014; Mayer, 2004; Wagensveld, Segers, Kleemans, \& Verhoeven; 2015).

Discovery occurs when individuals are involved, especially in the use of their mental processes to discover some concepts and principles. For example, the teacher presents a 
problem and students solve the problem until they find out the interrelationship. But because students in high school are not accustomed to find out own the solving of the problems presented, they still need the guidance of the teacher and the model is known as the guideddiscovery learning models. So that, the closeness between teachers and students keeps well (Herman, 2016; Rahmawati, Fitriana, \& Setiawan; 2017).

Cooperative learning model also can make students to be active. Cooperative learning enables skills in working as teams, skills that are in dire demand in the workplace. Jigsaw is type of cooperative learning model in which each student becomes a member of two groups, namely the member of the home group and the member of the expert group so that students do not get bored because the discussions during the lesson they not only meet in one group. Jigsaw cooperative learning model makes every student to be responsible and foster a desire / effort to understand the parts of the lessons to be learned and deliver the material to the other group members. So that students can develop the positive relationships among his friends who have different capabilities, to help friends who have difficulty in understanding mathematical concepts and improve self-esteem of student (Huda, 2016; Sari, 2017).

Based on the above description, the researcher is interested in conducting research with the title "The Difference of Students' Mathematical Achievement by Using Guided-Discovery and Cooperative Learning Model Jigsaw Type" and the purpose of this research is to know any difference of students' achievement in mathematics which using the model of guided discovery learning with cooperative learning model JIGSAW type.

\section{METHOD}

Type of research used in this study is a quasi experiment because students who are the subject of research have been formed in a particular group (in a class) so that the student may not be randomly selected. As a result, this type of experiment cannot be used to control the external variables that affect the doing of the experiment. In this study, two groups are randomly selected and then given different treatment, namely experimental class 1 taught by guideddiscovery learning model and experimental class 2 taught by cooperative learning model Jigsaw type. So the design of this experimental research is the post-test two experimental groups design (Cohen, Manion, \& Morrison, 2013).

This research was conducted at SMA N 3 Pematangsiantar with the population in this study is all of students at SMA N 3 P.Siantar registered in even semester in the academic year 2014/2015 and selected sample randomly which taken by cluster random sampling technique is class X-1 (36 students) as an experimental class I taught the guided-discovery learning model and class X-6 (36 students) as an experimental class II taught the cooperative learning model JIGSAW type. The sample is taken from population by assumption that the characteristics from both of classed are equal. Research instrument used is test which was tested the validity and reliability, to measure students' achievement in the cognitive domain at level knowledge, comprehension, application. To analyze the experimental result, would be used the test score of both of group. 


\section{RESULTS AND DISCUSSION}

\section{Results}

Based on the data of students' mathematics achievement who taught by guided-discovery learning model, the minimum score is 76 and the maximum score is 98. Based on the calculation, the mean score is 85.69 , the variance is 46.33 , the standard deviation is 6.81 .The frequency of students' mathematics achievement in experimental class I can be shown on Table 1.

Table 1. The Students' Mathematics Achievement in Experimental Class I

\begin{tabular}{ccccc}
\hline Interval & Predicate & Criteria & Total & $\begin{array}{c}\text { Precentage } \\
(\%)\end{array}$ \\
\hline $96-100$ & A & Very High & 3 & 8.33 \\
$90-95$ & $\mathrm{~A}^{-}$ & High & 8 & 22.22 \\
$86-89$ & $\mathrm{~B}$ & High & 6 & 16.67 \\
$80-85$ & $\mathrm{~B}^{-}$ & Low & 9 & 25.00 \\
$75-79$ & $\mathrm{C}^{-}$ & Low & 10 & 27.78 \\
$<75$ & $\mathrm{C}^{-}$ & Very Low & 0 & 0.00 \\
\hline & & Total & 36 & 100.00 \\
\hline
\end{tabular}

The data of distribution table can be drawn in bar diagram (histogram) that can be seen on Figure 1.

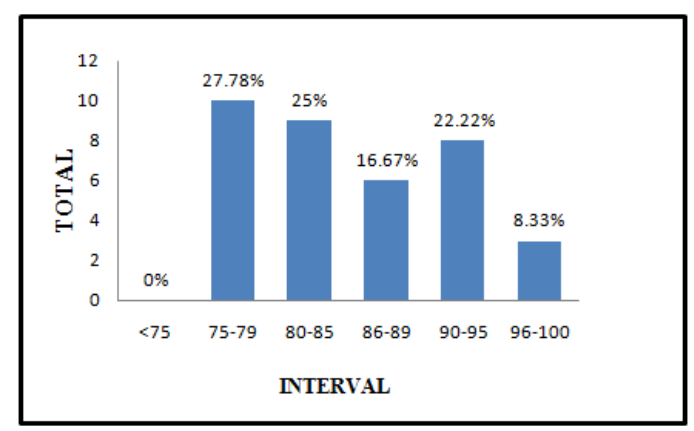

Figure 1. The Histogram of Students' Mathematics Achievement in Experimental Class I

From the above diagram can be seen that the students' mathematics achievement taught by guided-discovery learning model is not lower than KKM value. But, this following is Table 2 which showing the students' achievement for each indicator: 
Table 2. The Students' Mathematics Achievement in Experimental Class I For Each Indicator

\begin{tabular}{|c|c|c|c|c|c|c|c|}
\hline NO & Indicator & NI & SI & ST & SA & PA & PI \\
\hline 1. & $\begin{array}{l}\text { Determine trigonometri ratios } \\
\text { formulas of right triangle }\end{array}$ & 8 & 6 & 216 & 178 & 82.41 & 82.41 \\
\hline 2. & $\begin{array}{l}\text { Determine reverse formula of } \\
\text { trigonometry }\end{array}$ & 2 & 10 & 360 & 357 & 99.17 & 99.17 \\
\hline & $\begin{array}{l}\text { Use trigonometri identity to solve } \\
\text { problems }\end{array}$ & 4 & 8 & 288 & 262 & $\begin{array}{l}90.97 \\
85.67\end{array}$ & 88.31 \\
\hline & $\begin{array}{l}\text { Determine the value of } \\
\text { trigonometric ratios for specific } \\
\text { angle }\end{array}$ & 7 & 10 & 360 & 346 & $\begin{array}{l}91.67 \\
96.11\end{array}$ & 93.89 \\
\hline 7. & $\begin{array}{l}\text { Determine the value signs of } \\
\text { trigonometry in all quadrants }\end{array}$ & 6 & 10 & 360 & 210 & 58.33 & 58.33 \\
\hline & $\begin{array}{l}\text { Use trigonometric ratios formula to } \\
\text { solve problem in real life }\end{array}$ & 11 & 12 & 432 & 336 & $\begin{array}{l}77.78 \\
93.89\end{array}$ & 85.84 \\
\hline 10. & & 3 & 8 & 288 & 204 & 70.83 & \multirow[b]{2}{*}{80.25} \\
\hline 11. & $\begin{array}{l}\text { Determine trigonometric ratios } \\
\text { formula of related angles }\end{array}$ & $\begin{array}{l}9 \\
10\end{array}$ & 6 & 216 & 185 & 85.65 & \\
\hline
\end{tabular}

Note:

$\mathrm{NI} \quad=$ Number of item

SI $\quad=$ Score maximum for an item

ST $=$ Score total maximum of class for an item $(36 \times \mathrm{SI})$

SA $=$ Score total which is achieved by students for an item

PA = Students' achievement for an item

PI = Students' achievement for each indicator

From above, we can see that students' achievement for indicator which is lower than 75 is determine the value signs of trigonometry in all quadrants with just achieving 58.33. This indicator belongs to sub matter of the value sign of trigonometric ratio.

Based on the data of students' mathematics achievement who taught by cooperative learning model JIGSAW type, the minimum score is 61 and the maximum score is 94 . Based on the calculation, the mean score is 81.03 , the variance is 78.31 , the standard deviation is 8.85 .The frequency of students' mathematics achievement in experimental class II can be shown on Table 3. 
Table 3. The Students' Mathematics Achievement in Experimental Class II

\begin{tabular}{ccccc}
\hline Indicator & Predicate & Criteria & Total & $\begin{array}{c}\text { Precentage } \\
(\boldsymbol{\%})\end{array}$ \\
\hline $96-100$ & A & Very High & 0 & 0 \\
$90-95$ & $\mathrm{~A}^{-}$ & High & 6 & 16.67 \\
$86-89$ & $\mathrm{~B}$ & High & 9 & 25.00 \\
$80-85$ & $\mathrm{~B}^{-}$ & Low & 8 & 22.22 \\
$75-79$ & $\mathrm{C}$ & Low & 2 & 5.56 \\
$<75$ & $\mathrm{C}^{-}$ & Very Low & 11 & 30.55 \\
\hline & & Total & 36 & 100.00 \\
\hline
\end{tabular}

The data of distribution table can be drawn in bar diagram (histogram) that can be seen on Figure 2 .

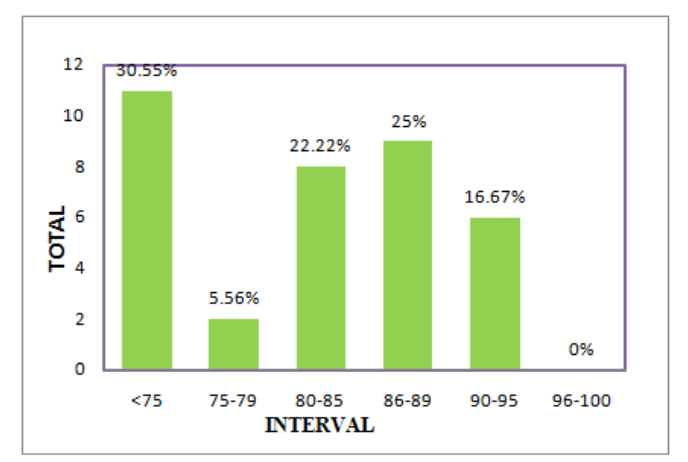

Figure 2. The Histogram of Students' Mathematics Achievement in Experimental Class II

From the above diagram can be seen that the students' mathematics achievement taught by cooperative learning model JIGSAW type, few of students get the score $<75$ with the total of 11 students (30.56\%). But, this following is Table 4 which showing the students' achievement for each indicator:

Table 4. The Students' Mathematics Achievement in Experimental Class II For Each Indicator

\begin{tabular}{clcccccc}
\hline $\begin{array}{c}\text { No. } \\
\text { Questions }\end{array}$ & \multicolumn{1}{c}{ Indicator } & NI & SI & ST & SA & PA & PI \\
\hline 1. & $\begin{array}{l}\text { Determine trigonometri ratios } \\
\text { formulas of right triangle }\end{array}$ & 8 & 6 & 216 & 188 & 87.04 & 87.04 \\
\hline 2. & $\begin{array}{l}\text { Determine reverse formula of } \\
\text { trigonometry }\end{array}$ & 2 & 10 & 360 & 343 & 95.28 & 95.28 \\
\hline 3. & $\begin{array}{l}\text { Use trigonometri identity to solve } \\
\text { problems }\end{array}$ & 4 & 8 & 288 & 188 & 65.28 & 62.97 \\
\hline. & 5 & 6 & 216 & 131 & 60.65 & 6 \\
\hline
\end{tabular}




\begin{tabular}{clcccccc}
\hline $\begin{array}{c}\text { No. } \\
\text { Questions }\end{array}$ & \multicolumn{1}{c}{ Indicator } & NI & SI & ST & SA & PA & PI \\
\hline 5. & $\begin{array}{l}\text { Determine the value of } \\
\text { trigonometric ratios for specific } \\
\text { angle }\end{array}$ & 7 & 10 & 360 & 360 & 100.00 & 93.41 \\
& $\begin{array}{l}\text { Determine the value signs of } \\
\text { trigonometry in all quadrants }\end{array}$ & 6 & 10 & 360 & 154 & 42.78 & 42.78 \\
\hline 7. & & & & & & \\
\hline 8. & Use trigonometric ratios formula to & 11 & 12 & 432 & 350 & 81.02 & 82.18 \\
9. & solve problem in real life & 12 & 10 & 360 & 300 & 83.33 & 82.18 \\
\hline 10. & Determine trigonometric ratios & 3 & 8 & 288 & 258 & 89.58 & \\
11. & formula of related angles & 9 & 6 & 216 & 171 & 79.17 & 85.88 \\
12. & 10 & 6 & 216 & 192 & 88.89 & \\
\hline
\end{tabular}

Note:

NI $=$ Number of item

SI $=$ Score maximum for an item

ST $=$ Score total maximum of class for an item (36 $\mathrm{x}$ SI)

SA = Score total which is achieved by students for an item

PA = Students' achievement for an item

PI = Students' achievement for each indicator

From above, we can see that students' achievement for indicator which is lower than 75 is use trigonometric identity to solve problems with just achieving 62.97 and determine the value signs of trigonometry in all quadrants. This indicator belongs to sub matter of trigonometric identity and the value sign of trigonometric ratio.

Based on above data, it is done testing hypothesis by using t-test. After testing the requirements of data analysis, it is known that the data used normal distribution and homogeneous. Therefore, testing the average difference of the two experimental classes using t-test with data normal and homogeneous.Summary of the study hypothesis test calculations results are presented in the following Table 5:

Tabel 5. Summary of t-Test Result

\begin{tabular}{ccc}
\hline Note & $\begin{array}{c}\text { Experimental } \\
\text { Class I }\end{array}$ & $\begin{array}{c}\text { Experimental } \\
\text { Class II }\end{array}$ \\
\hline $\mathbf{N}$ & 36 & 36 \\
$\overline{\boldsymbol{x}}$ & 85.69 & 81.03 \\
$\boldsymbol{S}^{\mathbf{2}}$ & 46.33 & 78.31 \\
$\boldsymbol{t}_{\text {calculation }}$ & \multicolumn{2}{c}{2.495} \\
$\boldsymbol{t}_{\text {table }}$ & \multicolumn{2}{c}{1.995} \\
Conclusion & \multicolumn{2}{c}{ Ho is rejected } \\
\hline
\end{tabular}

From the Table 5, it can be known that $t_{\text {calculation }}=2.495$ at $\alpha=0.05$ and $t_{\text {table }}=t_{(0.975,70)}=1.995$, then $t_{\text {calculation }}>t_{\text {table }}$ thus Ho is rejected. It means that there is the difference of students' achievement in mathematics which using guided-discovery 
learning model with using cooperative learning model jigsaw type in grade X SMA N 3 P. Siantar.

\section{Discussion}

Mathematics achievement test is given to both of classes after taught two different learning model to determine how the results of student achievement in the two classes after being given treatment. From the research, the average obtained by experimental class I is 85.69 and the experimental class II is 81.03.

Then testing the hypothesis by using $\mathrm{t}$ test and obtained $t_{\text {calculation }}=2.504$ at $\alpha=0.05$ and $t_{\text {table }}=t_{(0.975,70)}=1.995$, then $t_{\text {calculation }}>t_{\text {table }}$ (Ho is rejected). It means that there is the difference of students' achievement in mathematics which using the guided discovery learning model with cooperative learning model JIGSAW type in class X SMA N 3 P. Siantar.

This can be accepted because the guided discovery learning model enables students to discover, think self on the material being studied from the beginning to the end of the meeting. When student does not understand a subtopic and appears curiosity about it then he can ask a friend beside him or teacher, so that student will take seriously the explanation of a friend or teacher. As a result, student will have a more meaningful learning experience thus will take longer to remember the material they have learned.

Guided discovery learning model makes students are actively involved in the process of learning and the topics are usually intrinsically motivating, the activities used in discovery contexts are often more meaningful than the typical classroom exercises and textbook study, students acquire investigative and reflective skills that can be generalized and applied in other contexts and also builds on the students' prior knowledge and experience (Sabidin, Ismail, Tasir, Nihra, \& Said, 2014; Yuliana, Tasari, \& Wijayanti, 2017).

While the experimental class II, there are students who are less able to explain to home group members about subtopic which he is mastered, so that other members of the group are lack understand it, so need more time. In addition, in jigsaw group, there is advanced student dominates in discussing subtopic given, so that other students just record the answers without understanding the subtopic. This is same with revealing of Sugandi (2013) that the cooperative learning model JIGSAW type needs the ample research resources to complete their project, need to spend more time helping the less advanced students in jigsaw group, and the dominant students might try to control the jigsaw group so, other students do not understand the subtopics it and less able to explain it to his friend in home group.

However, in this study that there is weaknesses of researcher namely in the learning process, researcher can allocate time less well in both classes. Because the experimental class I, there were students who did not understand a subtopic and asked the teacher but as a brief discussion, the teacher was not able to guide the students. In the experimental class II, brief time discussing was conducted by a group of experts and they were not able to learn how to explain to the home group members about subtopic mastered because not all students have a great ability to give an explanation to his friends so easily understood. 


\section{CONCLUSION}

Based on the result of research, it can be concluded that: (1) There is difference of students' achievement in mathematics which using the model of guided discovery learning with cooperative learning model JIGSAW type in class X SMA N 3 P. Siantar; (2) Students who are taught by guided discovery learning model have the higher score that by cooperative learning model JIGSAW type.

\section{REFERENCES}

Cohen, L., Manion, L., \& Morrison, K. (2013). Research methods in education. London: Routledge.

Hendriana, H., Hidayat, W., \& Ristiana, M. G. (2018). Student teachers' mathematical questioning and courage in metaphorical thinking learning. In Journal of Physics: Conference Series (Vol. 948, No. 1, p. 012019). IOP Publishing.

Herman, T. (2016). Pengaruh Penerapan Model Pembelajaran Discovery Learning Terhadap Peningkatan Kemampuan Berpikir Kritis Matematis dan Self Confidence Siswa Kelas V Sekolah Dasar. EDUHUMANIORA: Jurnal Pendidikan Dasar, 7(2), 140-151.

Hidayat, W. (2017). Adversity Quotient dan Penalaran Kreatif Matematis Siswa SMA dalam Pembelajaran Argument Driven Inquiry pada Materi Turunan Fungsi. KALAMATIKA Jurnal Pendidikan Matematika, 2(1), 15-28.

Huda, M. K. (2016). Penerapan Pembelajaran Kooperatif Tipe Investigasi Kelompok untuk Meningkatkan Kemampuan Pemecahan Masalah Matematika Siswa pada Materi Persamaan Garis Lurus. Infinity Journal, 5(1), 15-24.

Janssen, F. J., Westbroek, H. B., \& van Driel, J. H. (2014). How to make guided discovery learning practical for student teachers. Instructional Science, 42(1), 67-90.

Martunis, M., Ikhsan, M., \& Rizal, S. (2014). Meningkatkan Kemampuan Pemahaman dan Komunikasi Matematis Siswa Sekolah Menengah Atas melalui Model Pembelajaran Generatif. Jurnal Didaktik Matematika, 1(2), 75-84.

Mayer, R. E. (2004). Should there be a three-strikes rule against pure discovery learning?. American psychologist, 59(1), 14.

Rahmawati, F., Fitriana, L., \& Setiawan, R. (2017). Eksperimentasi Model Pembelajaran Kuantum dan Discovery Learning terhadap Prestasi Belajar ditinjau dari Motivasi Belajar Siswa pada Materi Aturan Sinus, Kosinus, dan Luas Segitiga di SMA Negeri 5 Surakarta. Jurnal Pendidikan Matematika dan Matematika SOLUSI, 1(6), 82-91.

Sabidin, Z., Ismail, Z., Tasir, Z., Nihra, M., \& Said, H. M. (2014). A Meta-Analysis: Pedagogical Strategies for Teaching Mathematics among Aboriginal Students. In International Education Postgraduate Seminar 2014 (p. 552).

Sari, D. M. (2017). Analysis of Students'mathematical Communication Ability by using Cooperative Learning Talking Stick Type. Infinity Journal, 6(2), 183-194.

Sugandi, A. I. (2013). Pengaruh Pembelajaran Berbasis Masalah Dengan Setting Kooperatif Jigsaw Terhadap Kemandirian Belajar Siswa SMA. Infinity Journal, 2(2), 144-155.

Wagensveld, B., Segers, E., Kleemans, T., \& Verhoeven, L. (2015). Child predictors of learning to control variables via instruction or self-discovery. Instructional Science, 43(3), 365-379. 
54 Sitinjak \& Mawengkang, The Difference of Students' Mathematical Achievement ...

Yuliana, Y., Tasari, T., \& Wijayanti, S. (2017). The Effectiveness Of Guided Discovery Learning To Teach Integral Calculus For The Mathematics Students Of Mathematics Education Widya Dharma University. Infinity Journal, 6(1), 01-10. 